disposition of these are figured in the text, together with a map showing the point intensities in Holland.

It appears that altogether 17,550 chimneys were damaged, 3,000 in Courtrai alone, which represents 40 per cent of the possible number. There was no loss of life though ten people were slightly injured. Most people heard a sound as of the passage of a heavily laden cart, and several experienced two shocks, of which the second was the stronger. By the method of hyperboles the epicentre was found to be at geographic co.ordinates $50^{\circ} 47^{\prime} \mathrm{N}$., $3^{\circ} 35^{\prime} \mathrm{E}$., with an uncertainty of 4 or $5 \mathrm{~km}$. A diagram of the determination is given in the text. The depth of focus, using the Mohorovicic tables of $\bar{P}-P_{n}$ and
Gutenberg's corrections, was of the order of $45 \mathrm{~km}$., and this was confirmed by the formula for near stations.

$$
\text { Time of propagation of } \vec{P}=\frac{\sqrt{h^{2}+\Delta^{2}}}{V^{r}} \text {, }
$$

where $h$ is depth of focus, $\Delta$ is epicentral distance both in kilometres, and $Y$ is speed of wave taken as $5 \cdot 7 \mathrm{~lm} . / \mathrm{sec}$.

The initial time was calculated to be $10 \mathrm{~h} .57 \mathrm{~m} .42 \mathrm{~s}$. G.IY.T., and it was found that north-east and southwest of the epicentre compression was registered first, whilst in the other two quadrants dilatation was initially experienced. Readings for $P_{n} P^{*} \bar{P} \propto S_{n}$ and $S$ pulses for twenty-four stations in Europe are given together with a graph, and seven of the seismograms are reproduced. Six notable aftershocks have been noted.

\title{
SACRED FEASTS OF THE FOX INDIANS
}

\begin{abstract}
IN "Ethnography of the Fox Indians" by William Jones, edited by Margaret Welpley Fisher (Bureau Amer. Ethnol., Bull. 125 ; 1939), certain passages are tentatively identified with the contents of a sealed packet recording "ancient mysteries" of the Fox Indians, reported to have been among papers in the custody of the author's father (see NATURE of November 25, p. 914). These passages deal with "The Sacred Feast".

One kind of sacred feast is held in autumn, winter or spring. A man kills a deer and decides to pray. He informs a number of members of his own gens, say, the Eagle gens, of his intention, and each brings food, maple sugar, pumpkin, corn, etc. The prayer is held during the day, beginning in the morning. Waiters come to the lodge of the man getting up the feast and prepare the food; and invitations are then sent to others outside the gens. When the guests appear they find the Eagles waiting for them, seated at one end of the lodge, with the medicine bags spread out in front of them. They drum the air slowly with gourd rattles and ehant songs. Before the first singing and while the food is cooking, the Eagles say to themselves to which spirit the food is sacrificed. The sprinkling of tobacco accompanies the mention of each spirit's name. A period of silence follows, then when the food is cooked the second singing and the eating begin. All food must be eaten before the fourth singing begins, and at the close of the fourth singing all the people disperse.
\end{abstract}

At the summer feasts in the summer bark lodges there is added dancing. As soon as the corn ripens, thanksgiving feasts are held to which each gens invites members of the different gentes. These services are religious, preparatory to the thanksgiving dances. Each gens holds two services at which newly gathered corn is eaten as well as the flesh of a dog killed for the purpose. The inviting gens does not eat, but does the praying to the manitou for his goodness in giving them corn. Theso services are purely religious and no one comes unless invited.

In the same manner in the dances, such as the Wolf or Eagle Feast dances, dog, the principal thing eaten, is an offering made to Nanetowa to invoke his pleasure and presence at the dance, and no one comes to the dance unless he comes with the thought of coming into the presence of Manetowa. There is an atmosphere of sacredness; all enter silently and slowly, and there is no hilarity. During the dancing the men not taking part smoke or chew tobacco, while the women chew but do not smoke. The use of tobacco forms part of the rites to invoke Manetowa.

A feast is often held for the spirit of sickness so that he may not bring sickness. Ho has the power of granting long life. $\mathrm{He}$ is a manitou. Once a Winnebago-among the Winnebago, disease-giver was the most sacred of all their spirits-is said to have had the power of driving away the spirit of sickness. When the people were all dying of smallpox, he rode a white horse painted green and decked out gaily. He would run towards a house, yell at the spirit within, and strike against the lodge. This he did to drive out the spirit, and thereby gained many gifts.

Before a run is made on the buffalo, every camp makes a sacred feast to the buffalo, in which the food must be pumpkin or corn or maple-sugar ; always sugar together with the other two if possible. Dog or any other kind of meat is not used. The feast is made as soon as the hunters know they are in the vicinity of the buffalo.

In the buffalo dance the men and women imitate the run and movement of the buffalo when in flight. The leader in the dance has his head covered by a buffalo mane. Dog, corn and pumpkin are eaten.

The Mowitihagi," "Dirty Little Ant", otherwise known as "Those who worship the spotted calf", is a society in which many of the members belong to the Thunder gens. It is a most important society, ranking with the gentes in some of the buffalo ceremonies. At its dance a small image of a buffalo made of stone is brought out from the bag in which it is usually kept and placed on the floor halfway between two fires. It is about 8-10 inches long and 6-7 inches high, of red stone, and in every respect a representation of a buffalo bull. It is said to be alive and a manitou. In the dance, tobacco is offered to it. It is brought out twice a year only in the sacred feast of the Mowitihagi. 